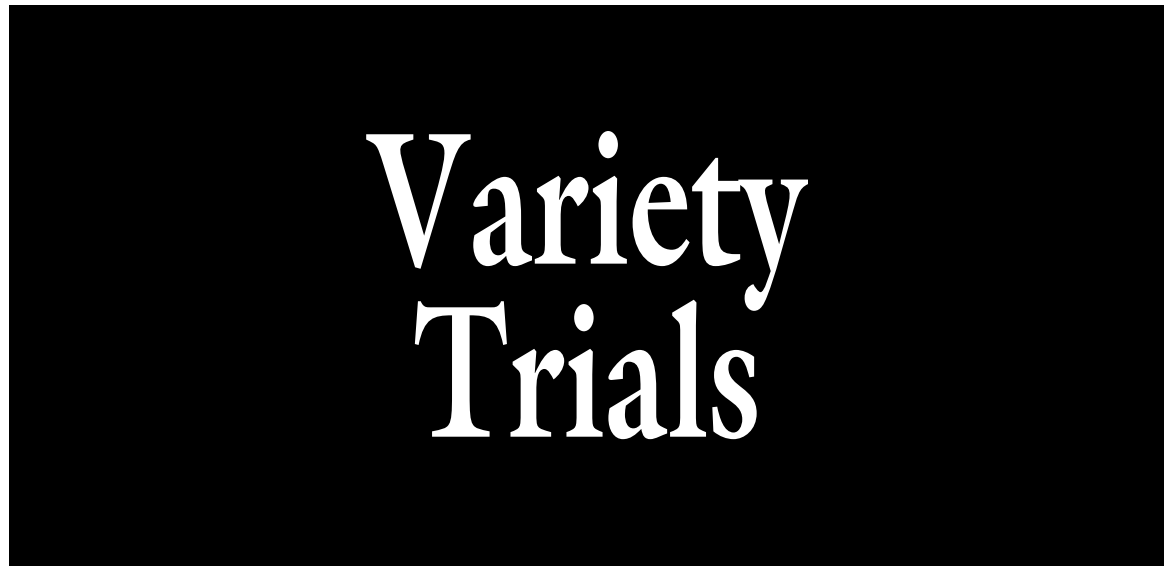

\title{
Evaluation of Seven Complex Pennisetum Hybrids for Container and Landscape Performance in the Pacific Northwestern United States
}

\author{
Ryan N. Contreras ${ }^{1,4}$, Jim Owen ${ }^{2}$, Wayne Hanna ${ }^{3}$, \\ and Brian Schwartz ${ }^{3}$
}

ADDITIONAL INDEX WORDs. napiergrass, fountaingrass, ornamental grass, millet

SUMMARY. Ornamental grasses such as fountaingrass or napiergrass, collectively called pennisetums, belong to the genus Pennisetum, which is a diverse genus with over 80 species adapted to a wide range of climatic regions and known for its drought tolerance. Breeding efforts have led to improvements such as more intense purple foliage color, disease resistance, and apparent sterility. These improved forms have been developed and tested in the eastern United States. The objective of this research was to evaluate container and field performance of seven new complex hybrid pennisetums in the Pacific northwestern United States. Two completely randomized experiments with three replications were conducted over 2 years (2010 and 2011) at two locations. We selected seven trispecific hybrid pennisetums resulting from interploid and interspecific crossing that were given accessions Tift 5 , Tift 6, Tift 10, Tift 11, Tift, 13, Tift 15, and Tift 26. Experiment 1 evaluated container performance in Corvallis, OR, while Expt. 2 evaluated field performance in Aurora, OR. Size index (SI), growth form rating, and color rating were collected and analyzed separately by location. In the container study, significant differences were observed among selections for growth form in 2010 and color ratings in both 2010 and 2011. In 2010, Tift 6, Tift 11, Tift 13, and Tift 15 had the highest growth form rating. For color rating, Tift 5, Tift 10, and Tift 26 were among the four highest rated selections in both years. In the field study, Tift 5 , Tift 10, Tift 11 , and Tift 26 had the highest SI when data were pooled over the 2 years, but all selections reached acceptable size for landscape use during both years of the study. Similarly, there were color differences among selections with Tift 5, Tift 10, Tift 15, and Tift 26 being highest rated. None of the selections survived below winter temperatures of $-5{ }^{\circ} \mathrm{C}$ at either location during either year of the study. Our evaluations indicate that these selections have potential in the Pacific northwestern United States as annuals. Differences in complex hybrid pennisetums were observed in SI, growth form rating, and color rating. These differences demonstrated the variation among selections and will allow producers to choose desired traits based on market preference.

rnamental grasses referred to as fountaingrass or napiergrass, collectively referred to as pennisetums, belong to the genus Pennisetum (Poaceae), which is a genus of $\approx 80$ species native to tropical, subtropical, and warm temperate regions (Huxley and Griffiths, 1992). The genus is known for drought tolerance, and the variety of species presents opportunities for novel ornamentals. For instance, napiergrass ( P. purpureum) has been selected for its ornamental purple foliage and includes selections such as 'Prince' and 'Princess' (Hanna and Ruter, 2005). Breeding at the University of Georgia led to hybrids that included complex interspecific, interploid crosses. Hanna et al. (2010) released 'Tift 17' and 'Tift 23' that included pearl millet $[P$. glaucum $(2 n=4 x=28)]$, napiergrass $(2 n=4 x=28)$, and a wild relative of pearl millet [P. squamulatum $(2 n$ $=8 x=56)]$ in their pedigrees. Ongoing breeding and selection has developed selections with deep purple foliage color, varied textures, disease resistance, and apparent sterility (seed and pollen). Recent selections, including those tested in the current research, were bred using germplasm with cytoplasmic male sterility, were selected to flower under short days $(<10.5 \mathrm{~h})$, and were the result of complex pedigrees; all of which contribute to their seedlessness. Furthermore, their roots are fibrous and the plant expands by producing tillers. This is in contrast to rhizomatous species that have the potential to spread vegetatively. The purpose of this research was to evaluate seven complex hybrid pennisetums developed at the University of Georgia for their potential as nursery and landscape plants for the Pacific northwestern region of the United States.

\section{Materials and methods}

PLANT MATERIAL. Bare root liners of seven pennisetums (Tift 5 , Tift 6 , Tift 10, Tift 11, Tift 13, Tift 15, and Tift 26) were received on 22 June 2010 and 3 Mar. 2011, respectively, for the 2 years of the study. The selections were the result of a breeding program that used germplasm with cytoplasmic male sterility, short day $(<10.5 \mathrm{~h})$ flowering selection, and complex pedigree that resulted in highly sterile plants. These selections were chosen for the study because they exhibited superior performance in previous evaluations. There was also a range of habits, from nearly prostrate to upright, and foliage colors. Liners were potted the day they were received into 0.7 -gal containers filled with bark-based soilless substrate composed of 7 douglas fir (Pseudotsuga menziesii) bark : 2 peat : 1 pumice (by volume). Potted containers were 
top-dressed with $16 \mathrm{~g} /$ pot of $18 \mathrm{~N}-$ 2.6P-9.9K controlled-release fertilizer (Apex; Simplot Professional Products, Lathrop, CA). Containers were maintained in a glasshouse with day/night set temperatures of $20 / 15^{\circ} \mathrm{C}$. In 2010 , plants were potted (for the container evaluation) or planted (for field evaluation) directly after being moved from the glasshouse as described below. In 2011, plants were moved on 4 April to an outdoor growing facility in Corvallis, OR, under microirrigation using spray stakes (Netafim USA, Fresno, CA) with a flow rate of 0.2 $\mathrm{L} \cdot \mathrm{min}^{-1}$ to maintain a 0.4 leaching fraction ( $140 \%$ of container capacity applied at each irrigation event). On 15 July 2010 and 19 May 2011 three replicates of the seven selections were either potted for container evaluation at the Corvallis, OR, location or moved to the Aurora, OR, location for field evaluation. At this time the plants had a mean growth index of $14.4 \mathrm{~cm}$ in 2010 and $36.0 \mathrm{~cm}$ in 2011 .

Growing Conditions. Plants were evaluated under container and field conditions. Container performance was evaluated in Corvallis, OR [U.S. Department of Agriculture (USDA) zone 8b (USDA, 2012)]. Plants were potted into 6.5-gal (\#10; Nursery Supplies, McMinnville, OR) containers filled with the bark-based soilless substrate described above and top-dressed with $140 \mathrm{~g} /$ pot of $18 \mathrm{~N}-$ 2.6P-9.9K controlled-release fertilizer (Apex). Plants were microirrigated using spray stakes (Netafim USA) as previously described. In 2010, there was a second container site in Corvallis, OR, under overhead irrigation that included three replications of the seven selections as well as the napiergrass cultivar Princess.

Field performance was assessed at the North Willamette Research and

\footnotetext{
We acknowledge Mara Friddle, Heather Stoven, and Mike Kapsimilis for their technical assistance and Alexander Kowalewski, Neil Bell, and anonymous reviewers for improvement of the manuscript through critical review.

${ }^{1}$ Department of Horticulture, OR State University, 4017 Agriculture and Life Sciences, Corvallis, OR 97331

${ }^{2}$ Department of Horticulture, Virginia Polytechnic Institute and State University, Hampton Roads Agricultural Research and Extension Center, Virginia Beach, VA 23455

${ }^{3}$ Department of Crop and Soil Sciences, University of Georgia, Tifton Campus, Tifton, GA 31793

${ }^{4}$ Corresponding author. E-mail: contrery@hort.
} oregonstate.edu.
Extension Center in Aurora, OR [USDA zone 8b (USDA, 2012)]. The native soil was 53B-Latourell loam (Fine-loamy, mixed, superactive, mesic Ultic Haploxeralfs) with $\approx 15 \%$ clay, $\mathrm{pH} 5.0$ to $6.5,10 \mathrm{meq} / 100 \mathrm{~g}$ soil cation exchange capacity, $0.5 \%$ to $2.0 \%$ organic matter, and $16 \%$ available water holding capacity (USDA, 1985). The soil was well drained and positioned on terraces with $0 \%$ to $3 \%$ slope. Mean soil temperature was 12.2 to $13.3{ }^{\circ} \mathrm{C}$ measured using an onsite certified weather station (Aurora, Oregon AgriMet Weather Station). Plants were placed on $3-\mathrm{m}$ centers in $\mathrm{l} \times \mathrm{l}-\mathrm{m}$ plots that were maintained weed free by hand weeding, mulched with 2 -inch douglas fir bark, and overhead irrigated as needed.

Measurements and ratings. Final size measurements and ratings were collected 22 Oct. 2010 and 27 Oct. 2011. Size index was calculated as $(\text { height } \times \text { width } 1 \times \text { width } 2)^{1 / 3}$; width 1 and width 2 were measured perpendicular to each other with one being at the widest point. Growth form rating was performed by having five individuals rate each plant on a 1 to 5 scale, where $\mathrm{l}=$ very poor growth form and $\mathbf{5}=$ excellent growth form. Individuals were allowed to use personal preference with regard to growth form; however, general guidelines were provided to base the rating on uniformity of growth and overall aesthetic impression. Individuals often regarded more upright selections with more tillers and finer texture as superior. Anecdotal information was collected on texture and habit of selections. Similarly, color rating was performed by five individuals rating each plant on color, where $\mathrm{l}=$ green and $\mathbf{5}=$ deep purple or red. The five ratings for growth form and color were averaged for each plant, such that for statistical analysis there was a single value for each plant. In 2011, when final measurements were made, the predominant leaf color of each selection was assigned to a color patch of the RHS Colour Chart (Royal Horticultural Society, 2007). Plants remained in situ overwinter without protection to assess survival. Leaves were not removed and therefore, may have provided minimal protection to the crown. To assess survival of the 2010 and 2011, we collected plantings survival ratings 1 May 2011 and 2012. Presence or absence of leaf spot (Helminthosporium sp.) was recorded at each location, but severity was not assessed. We also made anecdotal observations on leaf width, plant texture, and plant habit.

EXPERIMENTAL DESIGN AND DATA ANALYsIs. The experimental design at both locations was completely randomized with three replications for each of the seven hybrids. Data for each location were collected and analyzed separately. Size index, growth form rating, and color rating were subjected to analysis of variance using GLM procedures within SAS (version 9.2; SAS Institute, Cary, NC). When appropriate, interactions were analyzed using simple effects. When significant differences were observed means of main effects or simple effects were separated using Fisher's least significant difference at a 0.05 level of probability.

\section{Results and discussion}

Container PERFormance. Significant main effects and interactions for SI, growth form rating, and color rating for the container study were observed (Table 1). The significant year by selection interaction for SI was primarily the result of inconsistent performance of Tift 6 and Tift 10 from 2010 to 2011 . Inconsistent rankings for Tift 10 and Tift 15 between years also made the combined analysis of growth form and color rating inappropriate. Therefore, data were analyzed and presented separately by year (Table 2 ).

Significant differences were observed among selections for color rating in both 2010 and 2011 , as well as

\begin{tabular}{llll}
\hline $\begin{array}{l}\text { Units } \\
\text { To convert U.S. to SI, } \\
\text { multiply by }\end{array}$ & U.S. unit & SI unit & $\begin{array}{l}\text { To convert SI to U.S., } \\
\text { multiply by }\end{array}$ \\
\hline 0.3048 & $\mathrm{ft}$ & $\mathrm{m}$ & 3.2808 \\
3.7854 & $\mathrm{gal}$ & $\mathrm{L}$ & 0.2642 \\
2.54 & inch $(\mathrm{es})$ & $\mathrm{cm}$ & 0.3937 \\
1 & $\mathrm{meq} / 100 \mathrm{~g}$ & $\mathrm{cmol} \cdot \mathrm{kg}^{-1}$ & 1 \\
28.3495 & $\mathrm{oz}$ & $\mathrm{g}$ & 0.0353 \\
$\left({ }^{\circ} \mathrm{F}-32\right) \div 1.8$ & ${ }^{\circ} \mathrm{F}$ & ${ }^{\circ} \mathrm{C}$ & $\left({ }^{\circ} \mathrm{C} \times 1.8\right)+32$
\end{tabular}


Table 1. Analysis of variance table for size index, color rating, and rating of growth and form of hybrid pennisetum selections $(S)$ produced over 2 years $(\mathrm{Y})$ in containers or in a field in Corvallis, OR, and Aurora, OR, respectively.

\begin{tabular}{|c|c|c|c|c|}
\hline Source & df & MSE $^{\mathrm{z}}$ & $\mathbf{F}$ & $P$ \\
\hline \multicolumn{5}{|c|}{ Corvallis, OR (container performance) } \\
\hline \multicolumn{5}{|l|}{ Year $(Y)$} \\
\hline Size index & 1 & 703.3 & 7.0 & 0.0130 \\
\hline Growth form rating & 1 & 43.9 & 52.9 & $<0.0001$ \\
\hline Color rating & 1 & 10.5 & 19.7 & $<0.0001$ \\
\hline \multicolumn{5}{|l|}{ Selection (S) } \\
\hline Size index & 6 & 259.2 & 2.6 & 0.0399 \\
\hline Growth form rating & 6 & 5.0 & 6.1 & $<0.0001$ \\
\hline Color rating & 6 & 10.7 & 20.1 & $<0.0001$ \\
\hline \multicolumn{5}{|l|}{$\mathrm{Y} \times \mathrm{S}$} \\
\hline Size index & 6 & 310.8 & 3.1 & 0.0184 \\
\hline Growth form rating & 6 & 5.0 & 6.3 & $<0.0001$ \\
\hline Color rating & 6 & 6.8 & 12.8 & $<0.0001$ \\
\hline \multicolumn{5}{|c|}{ Aurora, OR (field performance) } \\
\hline \multicolumn{5}{|l|}{ Year $(\mathrm{Y})$} \\
\hline Size index & 1 & 26083.8 & 377.7 & $<0.0001$ \\
\hline Growth form rating & 1 & 1.7 & 2.0 & 0.1629 \\
\hline Color rating & 1 & 3.7 & 5.9 & 0.0162 \\
\hline \multicolumn{5}{|l|}{ Selection $(S)$} \\
\hline Size index & 6 & 434.5 & 6.3 & 0.0003 \\
\hline Growth form rating & 6 & 5.9 & 6.8 & $<0.0001$ \\
\hline Color rating & 6 & 9.7 & 15.3 & $<0.0001$ \\
\hline \multicolumn{5}{|l|}{$Y \times S$} \\
\hline Size index & 6 & 82.2 & 1.2 & 0.3401 \\
\hline Growth form rating & 6 & 9.8 & 11.1 & $<0.0001$ \\
\hline Color rating & 6 & 0.4 & 0.7 & 0.6638 \\
\hline
\end{tabular}

${ }^{\mathrm{z}}$ Mean square error.

Table 2. Comparison of seven selections of pennisetum hybrids grown in 6.5-gal (24.61-L) containers in Corvallis, OR, for size index, growth form rating, and color rating.

\begin{tabular}{|c|c|c|c|c|c|c|c|}
\hline \multirow[b]{2}{*}{ Selection } & \multicolumn{2}{|c|}{ Size index $(\mathrm{cm})^{\mathrm{z}}$} & \multicolumn{2}{|c|}{ Growth form rating $^{y}$} & \multicolumn{2}{|c|}{ Color rating ${ }^{x}$} & \multirow{2}{*}{$\frac{\text { RHS }^{w}}{2011}$} \\
\hline & 2010 & 2011 & 2010 & 2011 & 2010 & 2011 & \\
\hline Tift 5 & 119.7 & 114.8 & $2.3 \mathrm{~b}$ & 3.6 & $3.2 \mathrm{ab}$ & $4.1 \mathrm{~b}$ & $187-\mathrm{A}$ \\
\hline Tift 6 & 120.4 & 97.3 & $3.0 \mathrm{a}$ & 3.4 & $2.4 \mathrm{c}$ & $2.1 \mathrm{c}$ & $182-\mathrm{A}$ \\
\hline Tift 10 & 86.0 & 106.0 & $1.4 \mathrm{c}$ & 3.7 & $2.7 \mathrm{bc}$ & $4.7 \mathrm{a}$ & 187-A \\
\hline Tift 11 & 113.4 & 110.6 & $3.1 \mathrm{a}$ & 4.0 & $2.6 \mathrm{c}$ & $3.6 \mathrm{~b}$ & $184-\mathrm{B}$ \\
\hline Tift 13 & 115.8 & 98.4 & $3.1 \mathrm{a}$ & 3.5 & $2.4 \mathrm{c}$ & $2.3 \mathrm{c}$ & 176-A \\
\hline Tift 15 & 117.0 & 99.3 & $3.2 \mathrm{a}$ & 2.9 & $3.3 \mathrm{a}$ & $2.5 \mathrm{c}$ & $181-\mathrm{A}$ \\
\hline Tift 26 & 109.9 & 98.6 & $1.7 \mathrm{c}$ & 3.1 & $3.1 \mathrm{ab}$ & $3.6 \mathrm{~b}$ & $187-\mathrm{B}$ \\
\hline$P$ & 0.81 & 0.06 & $<0.0001$ & 0.09 & $<0.0001$ & $<0.0001$ & \\
\hline
\end{tabular}

${ }^{z}$ Size index calculated as (height $\times$ width $1 \times$ width 2$)^{1 / 3}$. Width 1 and width 2 measured perpendicular to each other with one measurement being at the widest point $(n=3) ; 1 \mathrm{~cm}=0.3937$ inch.

${ }^{y}$ Growth form rating presented as mean of five individuals ratings (subsamples) for each replicate for overall growth form; 1 = poor, 5 = excellent $(n=3)$.

${ }^{\mathrm{x}}$ Color rating presented as mean of five individuals ratings (subsamples) for each replicate for color; $1=$ green, $5=$ deep purple/red $(n=3)$.

wRHS Colour Chart (Royal Horticultural Society, 2007).

growth form rating in 2010 (Table 2). In 2010, Tift 6, Tift 11, Tift 13, and Tift 15 received the highest mean growth form ratings. There were no differences among selections for growth form rating in 2011, but all selections had improved ratings from 2010 except Tift 15 , which had a slight reduction in growth form rating, from 3.2 to 2.9 . Significant differences were observed for color rating among selections in 2010 and 2011 (Table 2). Tift 5, Tift 10, and Tift 26 were among the four highest rated selections for color in both years; these selections received consistently high color ratings that corresponded to patch $187 \mathrm{~A}$ or $187 \mathrm{~B}$ in the grayedpurple group of the RHS Colour Chart.

Field PERFormance. In the field study, the main effect of year was significant for SI and color rating, but the interactions between year and selection were not significant (Table 1). As these interactions were insignificant, we pooled SI and color rating across years (Table 3 ). A significant year by selection interaction for growth form was observed.

Differences existed among selections for SI with Tift 5, Tift 10, Tift 11 , and Tift 26 being the largest (Table 3). In 2010, Tift 6, Tift 11 , and Tift 13 received high growth form ratings, but in 2011 , Tift 5 , Tift 10 , Tift 11 , Tift 15 , and Tift 26 were highly rated and not statistically different from each other. Tift 10 received the highest color rating in the 2 years combined, followed by Tift 5 , Tift 11 , Tift 15 , and Tift 26 , which were not different from each other (Table 3). These selections with high color ratings all corresponded either to patch $185 \mathrm{~B}$, $187 \mathrm{~A}$, or $187 \mathrm{~B}$ in the grayed-purple group of the RHS Colour Chart.

No leaf spot was observed at the Corvallis container site using spray stakes or the overhead irrigated field site in Aurora. At the Corvallis site that received overhead irrigation in 2010 , leaf spot was observed on all three plants of 'Princess' and at least one plant of all selections being evaluated except Tift 11 (data not presented). Even though we did not conduct ratings to evaluate severity, it was clear that the seven selections being evaluated were more resistant to leaf spot than 'Princess'. Similarly, Hanna et al. (2010) observed increased resistance over 'Princess' in 'Tift 17' and 'Tift 23', which share a similar complex, three-species pedigree to the selections included in the current study.

Anecdotally, we observed variation in leaf width and overall plant texture (data not shown). Selections such as Tift 5 , Tift 10 , Tift 15 , and Tift 26 appeared to have wider leaves and coarser texture, similar to the napiergrass cultivars Prince and Princess (Hanna and Ruter, 2005), while Tift 6, Tift 11, and Tift 13 appeared to have thinner leaves and finer texture more like 'Tift 23' (Hanna et al., 2010).

In 2011, plants were planted $56 \mathrm{~d}$ earlier than in 2010. This likely 
Table 3. Comparison of seven selections of pennisetum hybrids field grown in Aurora, OR, for size index, growth form rating, and color rating pooled across years $(2010+2011)$ or by year when statistically appropriate.

\begin{tabular}{|c|c|c|c|c|c|}
\hline \multirow[b]{2}{*}{ Selection } & \multirow{2}{*}{$\frac{\text { Size index }(\mathrm{cm})^{\mathrm{z}}}{2010+2011}$} & \multicolumn{2}{|c|}{ Growth form rating ${ }^{y}$} & \multirow{2}{*}{$\frac{\text { Color rating }^{\mathrm{x}}}{2010+2011}$} & \multirow{2}{*}{$\frac{\text { RHS }^{w}}{2011}$} \\
\hline & & 2010 & 2011 & & \\
\hline Tift 5 & $135.0 \mathrm{ab}$ & $1.8 \mathrm{~d}$ & $3.3 \mathrm{ab}$ & $3.3 \mathrm{~b}$ & $187-B$ \\
\hline Tift 6 & $121.5 \mathrm{~cd}$ & $3.4 \mathrm{~b}$ & $2.5 \mathrm{c}$ & $2.3 \mathrm{c}$ & $185-B$ \\
\hline Tift 10 & $138.0 \mathrm{a}$ & $2.6 \mathrm{c}$ & $3.8 \mathrm{a}$ & $4.0 \mathrm{a}$ & $187-B$ \\
\hline Tift 11 & $125.2 \mathrm{bc}$ & $4.3 \mathrm{a}$ & $3.3 \mathrm{ab}$ & $3.2 \mathrm{~b}$ & $185-B$ \\
\hline Tift 13 & $113.1 \mathrm{~d}$ & $4.0 \mathrm{ab}$ & $2.9 \mathrm{bc}$ & $2.5 \mathrm{c}$ & 178-A \\
\hline Tift 15 & $121.7 \mathrm{~cd}$ & $2.7 \mathrm{c}$ & $3.2 \mathrm{abc}$ & $3.5 \mathrm{~b}$ & $185-B$ \\
\hline Tift 26 & $128.1 \mathrm{bc}$ & $2.1 \mathrm{~cd}$ & $3.2 \mathrm{abc}$ & $3.5 \mathrm{~b}$ & 187-A \\
\hline$P$ & $<0.0003$ & $<0.0001$ & 0.03 & $<0.0001$ & \\
\hline
\end{tabular}

${ }^{2}$ Size index calculated as (height $\times$ width $1 \times$ width 2$)^{1 / 3}$. Width 1 and width 2 measured perpendicular to each other with one measurement being at the widest point $(n=3) ; 1 \mathrm{~cm}=0.3937$ inch.

${ }^{y}$ Growth form rating presented as mean of five individuals ratings (subsamples) for each replicate for overall growth form; 1 = poor, 5 = excellent $(n=3)$.

${ }^{x}$ Color rating presented as mean of five individuals ratings (subsamples) for each replicate for color; $1=$ green, $5=$ deep purple/red $(n=3)$.

${ }^{w}$ RHS Colour Chart (Royal Horticultural Society, 2007).

accounted for the difference between years observed in SI in the field study. Mean SI for all selections was $101.2 \mathrm{~cm}$ in 2010 and $151.0 \mathrm{~cm}$ in 2011 , which was a $67 \%$ increase. There was a slight increase in SI in 2011 over 2010 in the container study but less than in the field site. In 2010, the mean SI was $103.6 \mathrm{~cm}$ and in 2011 , it was $111.8 \mathrm{~cm}$. It is possible that increased temperatures from growing in black plastic containers on black ground cloth accounted for the lack of marked difference in SI between years in the containerized plants.

There were differences in color between field and container evaluations. Selections were not consistently ranked between locations or between years. However, Tift 5 , Tift 10 , and Tift 26 were among the highest rated selections for color in both years of the container study and in the field study. In addition, Tift 15 was among the four highest rated selections in 2010 of the container study and in the field study. Selections also exhibited different habits in containers compared with the field. All selections were slightly more upright in containers. This was particularly noticeable in Tift 5 , Tift 11 , and Tift 26, which were lowergrowing and spreading in the field evaluation but upright-spreading in containers.

Ornamental Pennisetum selections with similar parentage are reported to be hardy in USDA hardiness zone 8 (Hanna and Ruter, 2005; Hanna et al., 2010), but none of the selections survived winter at any of the evaluation sites during either year. In Corvallis, plants were exposed to $37 \mathrm{~d}$ with temperatures below $0{ }^{\circ} \mathrm{C}$ and a low of $-7^{\circ} \mathrm{C}$ in 2010 to 2011 , and $40 \mathrm{~d}$ with temperatures below $0{ }^{\circ} \mathrm{C}$ and a low of $-5{ }^{\circ} \mathrm{C}$ in 2011 to 2012. In Aurora, plants were exposed to $34 \mathrm{~d}$ with temperatures below $0{ }^{\circ} \mathrm{C}$ and a low of $-8{ }^{\circ} \mathrm{C}$ in 2010 to 2011 , and $44 \mathrm{~d}$ with temperatures below $0{ }^{\circ} \mathrm{C}$ and a low of $-5{ }^{\circ} \mathrm{C}$ in 2011 to 2012. It is unclear why these selections were killed at temperatures that they have survived in previous field evaluations in Tifton, GA, during exposure to similar low temperatures. It is possible that overall cooler temperatures at the current locations or increased rainfall during winter led to mortality. Our findings indicate that in the Willamette Valley of Oregon, these selections will be annuals or potentially tender perennials if protected. However, their vigor, relative leaf spot resistance, and attractive foliage make several of them viable options for landscapes of the Pacific northwestern United States.

\section{Literature cited}

Hanna, W.W., S.K. Braman, and B.M. Schwartz. 2010. 'Tift 17' and 'Tift 23' hybrid ornamental Pennisetums [sic]. HortScience 45:135-138.

Hanna, W.W. and J.M. Ruter. 2005. 'Princess' and 'Prince' napiergrass. HortScience 40:494-495.

Huxley, A. and M. Griffiths (eds.). 1992. The new Royal Horticultural Society dictionary of gardening. Vol. 3. Macmillan, New York, NY.

Royal Horticultural Society. 2007. Royal Horticultural Society Colour Chart. 5th ed. Royal Horticultural Society, London, UK.

U.S. Department of Agriculture. 1985. Web soil survey. 28 Apr. 2009. <http:// websoilsurvey.nrcs.gov>.

U.S. Department of Agriculture. 2012. Plant hardiness zone map. 7 Feb. 2013. $<$ http://planthardiness.ars.usda.gov>. 